\title{
Tracking of Physical Activity from Childhood to Adulthood: A Review
}

\author{
Risto Telama \\ LIKES Research Institute, Jyväskylä, \\ Department of Sport Sciences, University of Jyväskylä, Finland
}

\author{
Key Words \\ Tracking · Obesity · Physical activity · Childhood . \\ Adulthood
}

\section{Summary}

The aim of the article was to review studies on the tracking of physical activity in all phases of life from childhood to late adulthood. The majority of the studies have been published since 2000. The follow-up time in most studies was short, the median being 9 years. In men, the stability of physical activity was significant but low or moderate during all life phases and also in longterm follow-ups. In women, the tracking was lower and in many cases non-significant. Among both sexes, stability seems to be lower in early childhood than in adolescence or in adulthood and lower in transitional phases, such as from childhood to adolescence or from adolescence to adulthood, than in adulthood. However, the differences in the stability of physical activity between age groups and between different phases of life were small. The number of tracking studies utilising objective methods to measure physical activity was so small that systematic differences in stability between self-report and objective methods could not be determined. A factor which caused differences in tracking results was the adjustment of correlations for measurement error and other error variance. Adjusted coefficients were clearly higher than unadjusted ones. However, adjustment was done only in very few studies. If the different methods used for estimating habitual physical activity and the failure to control for important covariates in studies of tracking are taken into account, physical activity appears to track reasonably well also in the longer term, for example from adolescence to adulthood. The results of the tracking studies support the idea that the enhancement of physical activity in children and adolescents is of great importance for the promotion of public health.

\section{Introduction}

The promotion of public health through physical activity interventions is based on the belief that physical activity is habitual and thus rather stable, in other words, it tracks over time. Tracking is usually defined as a tendency of individuals to maintain their rank or position within a group over time [1]. Tracking also means the ability to predict subsequent observations on the basis of earlier values [2]. The tracking of physical activity is especially important from the viewpoint of physical education. Nowadays, one of the most common aims of physical education in a great many countries is the promotion of a physically active lifestyle and life-long physical activity [3]. If successful, the enhancement of a physically active lifestyle should be trackable over long periods, such as from childhood to adulthood. If it is expected that physical activity at a young age, e.g. in school physical education or in youth sport, will have a favourable effect on public health, a high level of physical activity in youth should predict a high level of physical activity in adulthood.

Because many transitions and life-changing events experienced during the course of life influence physical activity, the level of tracking of physical activity is likely to vary at different phases of life. Therefore, information about the tracking of physical activity at different phases of life would be useful in the planning of interventions. On the one hand, tracking is a positive phenomenon. We hope that active children will also be active in adulthood and that new activities adopted in physical education and in interventions are maintained in the

\section{KARGER}

Fax +497614520714

Information@Karger.de

www.karger.com
(C) 2009 S. Karger GmbH, Freiburg

Accessible online at:

www.karger.com/ofa 
years to come. On the other hand, tracking has also a negative side. We know that some young people in all populations are inactive, which means, if the level of tracking is high, they will also be inactive later. Therefore, as pointed out by Corbin [4], it is important to emphasise the 'un-tracking' of inactivity and, in general, to keep the focus on the tracking of inactivity in tracking studies. Here, the concept inactivity means also very low activity and is not parallel with sedentary behaviour which is not necessarily a part of the physical activity continuum. The tracking of sedentary behaviour is not a topic of this review.

Because tracking means the tendency of individuals to maintain their rank or position within a group over time, the most often used indicator of tracking is Spearman's rank order correlation. Another method of showing tracking is to divide the distribution of physical activity into tertiles, quartiles, quintiles etc. and to show by cross-tabulation how individuals have stayed in the same position over time. Tracking coefficients show the stability or amount of variability of physical activity over long intervals of time. However, physical activity also varies over short intervals, e.g. from day to day or season to season, thus also influencing the tracking correlation. Therefore, more important than the type of tracking coefficient used is the adjustment of coefficients for error and shortterm variance, which is not part of the concept of tracking.

Table 1. Longitudinal tracking studies

\begin{tabular}{|c|c|c|c|c|c|c|}
\hline \multirow[t]{2}{*}{ Reference } & \multirow{2}{*}{$\begin{array}{l}\text { Number of } \\
\text { participants }\end{array}$} & \multirow{2}{*}{$\begin{array}{l}\text { Tracking from } \\
\text { age ... to }\end{array}$} & \multirow{2}{*}{$\begin{array}{l}\text { Assessment of physical } \\
\text { activity }\end{array}$} & \multicolumn{3}{|c|}{ Tracking coefficient } \\
\hline & & & & all & male & female \\
\hline \multicolumn{7}{|c|}{ Tracking in childhood and in adolescence } \\
\hline Jackson et al., 2003 [8] & 60 & $3-4$ & accelerometer & 0.40 & & \\
\hline Pate et al., 1996 [10] & 47 & $3-6$ & heart rate & 0.57 & & \\
\hline Kelly et al., 2007 [9] & 42 & $4-6$ & accelerometer & $0.35-0.37$ & & \\
\hline Hallal et al., 2006 [6] & 634 & $4-10$ & $\begin{array}{l}\text { mother report, } \\
\text { questionnaire }\end{array}$ & $\begin{array}{l}\text { significant } \\
\text { tracking }\end{array}$ & & \\
\hline Oja and Jürimae, 2001 [5] & 294 & $6-8$ & mother report & & NS & NS \\
\hline Nyberg et al., 2009 [11] & 97 & $7.5-9$ & Actiwatch & & 0.72 & 0.51 \\
\hline Raudsepp and Päll, 1998 [12] & 42 & $8-10$ & Caltrac accelorometer & $0.34-0.57$ & & \\
\hline Kristensen et al., 2008 [22] & 444 & $9-15$ & $\begin{array}{l}\text { MTI actigraph: } \\
\text { crude } \\
\text { adjusted }\end{array}$ & & $\begin{array}{l}0.18 \\
0.53\end{array}$ & $\begin{array}{l}0.19 \\
0.48\end{array}$ \\
\hline Telama et al., 1994 [51] & $\begin{array}{l}465 \\
503\end{array}$ & $\begin{array}{l}9-15 \\
12-15\end{array}$ & short questionnaire & & $\begin{array}{l}0.34 \\
0.51-0.53\end{array}$ & $\begin{array}{l}0.21 \\
0.42-0.48\end{array}$ \\
\hline McMurray et al., 2003 [19] & 791 & $9-16$ & questionnaire & & $0.18-0.37$ & $0.23-0.26$ \\
\hline Janz et al., $2000[18]$ & 126 & $10-15$ & interview VPA & & 0.32 & 0.43 \\
\hline Pate et al., 1999 [20] & 181 & $11-14$ & $\begin{array}{l}\text { previous day recall: } \\
\text { VPA } \\
\text { Kcal }\end{array}$ & & $\begin{array}{l}0.23 \\
0.38\end{array}$ & $\begin{array}{l}0.23 \\
0.25\end{array}$ \\
\hline Bagget et al., 2008 [13] & 951 & $12-14$ & $\begin{array}{l}\text { actigraph } \\
\text { 3-D self-report }\end{array}$ & & & $\begin{array}{l}0.25-0.33 \\
0.17-0.22\end{array}$ \\
\hline Raudsepp et al., 2008 [14] & 345 & $12-14$ & $\begin{array}{l}\text { 3-day recall: } \\
\text { METs } \\
\text { VPA }\end{array}$ & & $\begin{array}{l}0.36 \\
0.40\end{array}$ & $\begin{array}{l}0.42 \\
0.30\end{array}$ \\
\hline Aarnio et al., 2002 [16] & 2,934 & $16-18$ & short questionnaire & & 0.56 & 0.44 \\
\hline
\end{tabular}

Tracking in adulthood

Fortier et al., 2001 [26]

Telama et al., 2005 [27] De Bourdeaudhuij et al.,
2002 [25]

$\begin{array}{rrr}>1,000 & 15-69 & \text { questionnaire } \\ 1,563 & 18-27 & \text { questionnaire } \\ & 18-30 & \\ & 18-33 & \\ & 18-36 & \\ & 18-39 & \\ 172 & 20-27 & \text { questionnaire }\end{array}$

$172-20-27$

questionnaire
$0.04-0.39$

$\begin{array}{ll}0.61 & 0.31 \\ 0.44 & 0.39 \\ 0.35 & 0.42 \\ 0.43 & 0.29 \\ 0.33 & 0.26 \\ \text { NS } & 0.34-0.41\end{array}$

Table 1 to be continued on next page 
Table 1. Continued

\begin{tabular}{|c|c|c|c|c|c|c|}
\hline \multirow[t]{2}{*}{ Reference } & \multirow{2}{*}{$\begin{array}{l}\text { Number of } \\
\text { participants }\end{array}$} & \multirow{2}{*}{$\begin{array}{l}\text { Tracking from } \\
\text { age ... to }\end{array}$} & \multirow{2}{*}{$\begin{array}{l}\text { Assessment of physical } \\
\text { activity }\end{array}$} & \multicolumn{3}{|c|}{ Tracking coefficient } \\
\hline & & & & all & male & female \\
\hline Parsons et al., 2006 [31] & 9,769 & $\begin{array}{l}23-42 \\
23-33\end{array}$ & questionnaire & & $\begin{array}{l}0.16 \\
0.20\end{array}$ & $\begin{array}{l}0.12 \\
0.11\end{array}$ \\
\hline Anderssen et al., 1996 [24] & 5,115 & $24-31$ & interview & & $0.42-0.49$ & $0.34-0.41$ \\
\hline Friedman et al., 2008 [29] & $\begin{array}{l}449 \\
689 \\
628\end{array}$ & $\begin{array}{l}25-66 \\
39-66 \\
49-66\end{array}$ & questionnaire & & $\begin{array}{l}0.15 \\
0.22 \\
0.21\end{array}$ & $\begin{array}{l}0.13 \\
0.16 \\
0.24\end{array}$ \\
\hline Sallis et al., 2001 [30] & 226 & $31-38$ & interview & & & 0.30 \\
\hline Kirjonen et al., 2006 [28] & 546 & $\begin{array}{l}40-68^{a} \\
40-50^{a} \\
40-45^{a}\end{array}$ & $\begin{array}{l}\text { interview physical activity } \\
\text { time }\end{array}$ & & $\begin{array}{l}0.19 \\
0.25 \\
0.46\end{array}$ & $\begin{array}{l}0.18 \\
0.29 \\
0.34\end{array}$ \\
\hline Tudor-Locke et al., 2008 [23] & 1,175 & $42-43$ & pedometer & & $0.54-0.65$ & $0.20-0.61$ \\
\hline Mulder et al., 1998 [74] & 1,400 & $50-54$ & questionnaire & $0.25-0.38$ & & \\
\hline $\begin{array}{l}\text { Armstrong and Morgan, } \\
1998 \text { [75] }\end{array}$ & 1,042 & $65-73$ & $\begin{array}{l}\text { questionnaire: } \\
\text { outdoor activity } \\
\text { walking } \\
\text { strength activity }\end{array}$ & & $\begin{array}{l}0.50 \\
0.45 \\
0.49\end{array}$ & $\begin{array}{l}0.58 \\
0.18 \\
0.56\end{array}$ \\
\hline \multicolumn{7}{|c|}{ Tracking from young age to adulthood } \\
\hline Richards et al., 2007 [21] & 829 & $\begin{array}{l}7-21 \\
9-21\end{array}$ & family report and interview & $\begin{array}{l}0.09 \\
0.11\end{array}$ & & \\
\hline Telama et al., 2005 [27] & 1,563 & $\begin{array}{l}9-30 \\
9-27 \\
9-24\end{array}$ & questionnaire & & $\begin{array}{l}0.35 \\
0.28 \\
0.31\end{array}$ & $\begin{array}{l}0.17 \\
\mathrm{NS} \\
0.21\end{array}$ \\
\hline Trudeau et al., 2004 [32] & 166 & $9-35$ & diary & 0.20 & & \\
\hline Parsons et al., 2006 [31] & 9,769 & $\begin{array}{l}11-42 \\
16-42\end{array}$ & questionnaire & & $\begin{array}{l}0.03 \\
0.09\end{array}$ & $\begin{array}{l}\text { NS } \\
0.07\end{array}$ \\
\hline Friedman et al., 2008 [29] & 1,277 & $11-66$ & parent report, questionnaire & & 0.14 & 0.12 \\
\hline Herman et al., 2008 [37] & 374 & $\begin{array}{l}12-27^{\mathrm{b}} \\
12-34^{\mathrm{b}}\end{array}$ & questionnaire & & $\begin{array}{l}\text { significant } \\
\text { NS }\end{array}$ & $\begin{array}{l}\text { significant } \\
\text { NS }\end{array}$ \\
\hline Telama et al., 2005 [27] & 1,563 & $\begin{array}{l}12-33 \\
15-36 \\
18-39\end{array}$ & questionnaire & & $\begin{array}{l}0.33 \\
0.44 \\
0.33\end{array}$ & $\begin{array}{l}0.23 \\
\mathrm{NS} \\
0.26\end{array}$ \\
\hline Anderssen et al., 2005 [34] & 455 & $13-21$ & questionnaire, (WHO) & & 0.15 & 0.09 \\
\hline Twisk et al., 2000 [76] & 181 & $13-27$ & interview GEE & 0.34 & & \\
\hline Vanreusel et al., 1997 [56] & 236 & $13-35$ & interview & $0.14-0.20$ & & \\
\hline Scheerder et al., 2006 [44] & 257 & $\begin{array}{l}13-35 \\
16-35\end{array}$ & questionnaire & & & $\begin{array}{l}\text { NS } \\
0.41\end{array}$ \\
\hline Tammelin et al., 2003 [42] & 7,794 & $14-31$ & questionnaire & significant $\mathrm{p}$ & ediction & \\
\hline Beunen et al., 2004 [39] & 166 & $\begin{array}{l}14-40 \\
16-40\end{array}$ & questionnaire & & $\begin{array}{l}\text { NS } \\
0.22\end{array}$ & \\
\hline Boreham et al., 2004 [35] & 268 & $15-22$ & questionnaire & & 0.20 & NS \\
\hline Engström, 1991 [41] & 2,000 & $15-30$ & questionnaire & significant & & \\
\hline Glenmark et al., 1994 [36] & 105 & $16-27$ & questionnaire R2 & & 0.28 & 0.66 \\
\hline $\begin{array}{l}\text { Barnekow-Bergkvist, } \\
1998 \text { [38] }\end{array}$ & 278 & $16-34$ & questionnaire & & 0.28 & 0.27 \\
\hline Matton et al., 2006 [43] & 138 & $16-41$ & $\begin{array}{l}\text { questionnaire sport } \\
\text { participants }\end{array}$ & & & NS \\
\hline Andersen et al., 1993 [33] & 202 & $17-25$ & questionnaire, 1-year recall & & 0.31 & NS \\
\hline Scott and Willits, 1989 [40] & 1,298 & adolescents $>50$ & questionnaire & & 0.14 & 0.25 \\
\hline
\end{tabular}

NS = Not significant.

${ }^{\mathrm{a}} 40$ is mean age at baseline, range $18-68$ years.

${ }^{\mathrm{b}} 12$ is mean age at baseline, range $7-18$ years. 
Malina [1] published his often cited review on the tracking of physical activity in 2001. Interest in the tracking of physical activity has increased notably since then. The majority of longitudinal tracking studies have been published after 2000, and articles published during the last few years show that the activity in this field continues unabated (table 1). Not only has the number of tracking studies increased after 2001 but there is also a qualitative development in the field indicated, e.g. by the use of objective methods of measuring physical activity and more sophisticated methods to analyse tracking. The aim of this article is to review physical activity tracking studies. The main focus is on longitudinal studies but some retrospective studies have also been included especially when the question addressed is how well previous physical activity predicts current activity. The search words used were tracking/stability and physical activity/sport participation. The data bases were PubMed and SportDiscus. Only articles available in English were accepted. The follow-up time in the reviewed studies ranged from 1 to 55 years, with a median of 9 years. Below, the tracking results are discussed in three categories: tracking in childhood and adolescence, in adulthood, and from childhood and adolescence to adulthood. Because many different statistical procedures and methods to measure or assess physical activity have been used, the coefficients presented in the text and in table 1 are only partially comparable.

\section{Tracking of Physical Activity in Childhood and Adolescence}

Only a few studies have reported on the stability of physical activity among pre-school age children. In a study in which 6year-old children's physical activity measured through mother's report was followed over 18 months, the most tracking correlations were not significant [5], while in another study, also using mother's estimation of physical activity, the level of tracking from age 4 to 6 was significant [6]. Direct observation of physical activity from age 4 to 6 also showed a significant but low correlation of tracking $(\mathrm{r}=0.27)$ [7]. The studies using more objective methods to measure physical activity have reported a somewhat higher level of tracking across follow-up of a few years: in two studies using an accelerometer, $\mathrm{r}$ was $0.35-0.40[8,9]$, and in a study with heart rate recording, r was 0.57 [10]. It seems that some stability, at least on a low or moderate level, exists in young children's physical activity when the measurement validity is high enough. Accelerometer measurements during the first school years show a somewhat higher stability of physical activity than measurements in pre-school age $[11,12]$.

At least five studies have investigated the tracking of physical activity during the adolescent years. From studies using 3-day self-report with the same follow-up time, from 12 to 14 years, one reported low tracking $(0.17-0.22)$ [13] and another one moderate tracking (0.30-0.42) [14]. A Finnish study following adolescents over 3 years from age 12 to 15 presented correlations in two cohorts of 0.51 and 0.53 for boys and 0.42 and 0.48 for girls. The stability coefficients attenuated for reliability by the Simplex model were 0.65 and 0.72 for boys and 0.53 and 0.68 for girls [15]. Another study applying a short questionnaire resulted in a tracking correlation over 2 years of 0.56 for boys and 0.44 for girls [16]. Physical activity determined by a pedometer showed a tracking coefficient of 0.55 over 3 years and 0.35 over 5 years in boys, whereas in girls the correlations were non-significant [17].

The transition from childhood to adolescence is interesting from the viewpoint of physical education and the development of lifestyle. Studies based on self-report measures have reported low or moderate tracking from childhood to adolescence of $0.13-0.43$ [18-21]. Also, the tracking of physical activity measured with an accelerometer was found to be very low, from 0.18 to 0.19 from the age $10-12$ to $14-16$, but was higher (boys 0.53 , girls 0.48 ) when the coefficients were adjusted for random error due to day-to-day variation and within instrumental measurement error [22].

\section{Tracking of Physical Activity in Adulthood}

An Australian study reported moderate or moderately high tracking over 1 year when physical activity was measured by a pedometer over 7 days, with $r$ varying from 0.52 to 0.65 , with the exception that in one female cohort $r$ was 0.34 [23]. There were no clear differences between age groups from 30 to 60 years. Three studies reported on the stability of physical activity among young adults (18-32) over 7 years. The tracking coefficients varied from 0.35 to 0.42 in female participants and from 0.35 to 0.49 in male participants, with one study showing a non-significant relationship for male subjects [24-26]. The correlations for comparable age groups in a Finnish study over 9 years were 0.61 for male and 0.31 for female participants from age 18 to 27 and 0.58 and 0.51 from age 21 to 30, respectively [27]. In another Finnish study, stability over 5 years in 18- to 64-year-olds was 0.46 and 0.34 for male and for female subjects, and stability over 10 years was 0.25 and 0.29 , respectively [28]. The 4-year tracking correlation in an American study from age 25 to 29 was 0.21 for both sexes [29], and another American study showed a correlation of 0.30 in a follow-up of female participants from age 31 to 38 [30]. Few studies have reported long-term tracking correlations in adulthood. In a Finnish study among 18- to 64year-olds, the tracking correlation over 28 years was 0.19 for male and 0.18 for female participants. Here, the correlation may be influenced by the dropout of older participants due to mortality [28]. In the Young Finns Study, the tracking correlation over 21 years for 18 - to 39-year-olds was 0.33 for men and 0.26 for women [27]. 


\section{Tracking from Childhood and Adolescence to Adulthood}

The tracking of physical activity from childhood to adulthood has been shown to be very low or non-significant. From age 11 to 42 , the correlation was only 0.03 for men and non-significant for women [31], 0.20 from age 8 to 34 among both sexes [32], and from age 9 to 30 it was 0.35 in male and 0.17 in female subjects [27]. The correlation for sport club participation from age 7 to 21 was 0.09 and from 9 to 21 it was 0.11 in a group of boys and girls [21].

The majority of published tracking studies concerns the period from adolescence to adulthood. The tracking coefficients from adolescence to young adulthood ( $<30$ years) for male subjects varied from 0.15 to 0.44 [27, 33-36]. One study on men reported a non-significant relationship [26]. Only a few studies have reported significant tracking correlations from adolescence to young adulthood for female participants, the coefficients ranging from 0.09 to 0.34 [27, 34, 37]. In addition, one study found that physical activities at age 16 strongly predicted physical activity at age 27 among female participants, $\mathrm{r}=0.66$ [36]. Three studies reported non-significant tracking from adolescence to young adulthood among women [26, 33, 35]. Tracking of physical activity from adolescence to young adulthood seems to be low or non-significant, especially in female participants.

The coefficients showing the stability of physical activity from adolescence to adulthood at age $\geq 30$ vary from 0.14 to 0.44 among men [27, 38-40]. Only one non-significant relationship was found in male subjects [37]. Among female participants, the corresponding coefficients varied from 0.23 to $0.41[27,38,40]$. Two studies reported a significant relationship for both sexes [41, 42]. In three studies, a non-significant relationship was found in at least one age cohort in female participants [27, 43, 44]. A significant relationship between adolescent and adult physical activity has also been confirmed by retrospective studies [45-48]. Among men, the long-term stability of physical activity from adolescence to adulthood seems to be low but significant. In female participants, the many non-significant relationships indicate poorer stability compared to men.

One study, based on very old data, found a significant relationship between physical activity at age 11 and $67: \mathrm{r}=0.14$ for male and 0.12 for female participants [29]. This very long stability of physical activity has been supported by retrospective studies $[49,50]$.

\section{Factors Related to Tracking}

Among the many factors affecting the tracking of physical activity, the follow-up time, method of assessing physical activity, gender and age of subjects, and type of physical activity will be discussed here. The influence of the follow-up time cannot be seen from the overview, as this concerns different age groups, different measurement methods, and subjects from different cultural environments. When the baseline age was 18 and the same method was used to assess physical activity in a Finnish population, the tracking correlation for male participants varied according to the follow-up time as follows: 3 years 0.58 , 6 years $0.50,9$ years $0.47,12$ years $0.44,15$ years $0.35,18$ years 0.43 , and 21 years 0.33 . The respective correlations for female participants were $0.48,0.42,0.41,0.39,0.42,0.29$, and 0.26 . The first three coefficients concerned the same individuals. The other figures represented different age cohorts [27, 51]. The decline in the coefficients along follow-up time is rather linear, however, here it is also important to take the possible influence of life changes in young adulthood into account.

The differences found in stability between the measurement methods were not large when the tracking time was the same. However, it must be remembered that objective methods of measurement have been used in rather few studies. In pre-school age children, objective methods, such as the use of an accelerometer or heart rate recording, have shown higher stability than, for example, mother's estimation or direct observation. Otherwise it is difficult to see systematic differences between objective and recall methods. One reason for the similarity between self-report and objective methods may be that although objective methods measure physical activity more accurately during the measurement itself, their ability to capture a sufficient sample of the individual's activities or day-today variation may be lower than that of self-report. Recording usually covers a few days or, at most, 1 week. The self-report method in turn may better capture on various activities, including, for instance, seasonal variation, but involves a larger measurement error than is the case in objective methods due to difficulties in recalling or estimating one's own behaviour. In any case, objective methods should be used in the study of the stability of physical activity and attention should be paid to the adequate coverage of time and activities in recording.

A gender difference was clearly seen in the results of the physical activity tracking studies. Tracking coefficients were in many cases lower and more often non-significant in women than in men. One reason may be the lower participation rate among female than among male subjects. Another reason may be connected with the major transitions in the course of life, such as the transition from schooling to employment or from singlehood to marriage and having children, experiencing unemployment etc., which may influence physical activity and its stability. In adulthood, the gender difference in the stability of physical activity may be caused by the fact that many life changes have a greater influence on the physical activity of women than men $[52,53]$. The gender differences in tracking may also be explained by the changes in opportunities for physical activity among women, especially related to fitness centres.

Although it can be reasonably expected that the stability of physical activity will be different due to different 
developmental phases and various transitions in different phases of life, it is difficult to see any systematic age differences in the tracking coefficients reported in the reviewed studies. When physical activity was assessed with the same self-report method in four age groups, the tracking correlations over 3 years were $0.50,0.53,0.66$, and 0.67 for $9-, 12-$, $15-$, and 18-year-old male subjects and $0.47,0.48,0.57$, and 0.58 for female subjects, respectively, in both cases showing a slight growth with age. However, the growth of correlations with age disappeared when the correlations were corrected for reliability, which was lower in the younger than in the older groups [15]. In order to study age differences in the real stability of physical activity, the objective method should be used in different age groups drawn from the same population. Tudor-Locke et al. [23] studied tracking over 1 year in a large adult population aged from 20 to $>60$ and found no systematic age differences, with the exception that in women $>60$ years the correlation was lower $(0.30)$ than it was in the other groups (average for men 0.57 and for women 0.55 ).

The level of reliability and tracking of physical activity seems to vary according to the type of activity. In particular, organised activities, such as participation in a youth sport programme, are easier to recall than unorganised recreational activities because organised activities generally follow a regular timetable. The tracking of the item concerning participation in sport club training was found to be better than the tracking of other items in a physical activity inventory $[15,51]$. A rather high tracking coefficient (general estimation equation, GEE) for sport club participation from childhood to young adulthood was also found in a study in New Zealand [21]. Other variables that are easy to recall and which have been found to be good predictors of adult physical activity are participation in sport competitions and physical education grade in school [36, 41, 45, 49, 54].

The tracking of physical activity means that it is a good thing for physical education and public health when active individuals maintain their level of activity. However, tracking of physical inactivity or low activity is in turn clearly less desirable. There is some evidence that inactivity tends to track better than activity [17, 34, 43, 55-57]. In future research, more emphasis should be paid to the tracking of inactivity and, in general, to those who are inactive, as pointed out by Corbin [4].

In his review, Malina [1] mentioned the cultural background as a possible factor affecting the tracking of physical activity. As an example he presented higher level tracking results from Finland and from other Nordic countries as compared to results from the USA and some other countries. Cultural context was also mentioned in a Norwegian study as a possible factor for influencing the tracking of physical activity concerning recreational outdoor activity in particular [57]. In Norway, most adolescents have daily access to nature, recreation parks, and outdoor activity areas. The same can be said about the cultural context in Finland. No statistical analysis on the differences in tracking of physical activity between different cultural contexts has been carried out for this review because of the different follow-up times, methods of assessment of physical activity, and age groups. However, a non-systematic overview may give some support to cultural differences, in particular among women.

\section{What Is behind Tracking?}

Why do some people maintain their physical activity over long time periods while others stay inactive? Physical education and other measures to promote an active lifestyle are based on expectations that physical activity will be maintained to some extent in the long term. From the viewpoint of developing promotional measures it is important to know what factors explain or are connected with the tracking of physical activity during adulthood or from school age to adulthood. If, for instance, tracking is mainly explained by genetic factors, measures to enhance a physically active lifestyle will not be so effective. Four approaches to this issue are discussed here: the 'carry-over value hypothesis', 'ability and readiness hypothesis', 'habit formation hypothesis', and 'self-selection hypothesis'.

The carry-over value hypothesis presented by physical educators suggests that in adulthood people continue to participate in the activities they engaged in at a young age. Therefore, such lifestyle activities should be taught in school [58-60]. The tracking of the same type of physical activity from school age to adulthood has been little studied. A Finnish study showed that adolescents who participated in endurance type of sport or in women's gymnastics also had a higher probability of participating in the same kinds of activities 17 years later [61]. A similar relationship between adolescent and adult participation was found in many activities in a Norwegian study in which the follow-up time was only 8 years [57]. A retrospective study has reported a similar relationship for swimming [62]. In some activities, participation at a young age may increase the probability of participation in adulthood but otherwise adult physical activity does not seem to depend on the type of activity practised in youth. The typical sport activities practised at a young age and in adulthood are generally different. Playing soccer or ice hockey regularly in youth predicted high physical activity in adulthood in Finnish males although rather few of them continued to play soccer or ice hockey in adulthood [27, 61]. A recent Norwegian study showed that the number of activities participated in during adolescence is more important for the later physical activity than the participation in any specific activities [57]. Thus, the carry-over hypothesis explains a part of the tracking from young age to adulthood but cannot be the main explanation of the tracking of physical activity in general. 
It has been found that those who have participated persistently in physical activity or organised sport in youth for $>3$ years much more often belong to the highest tertile of physical activity in adulthood 21 years later than those who were inactive at a young age or those who did not participate in youth sport [27, 63]. Organised youth sport has also been found to be a good predictor of adult physical activity in other longitudinal studies $[38,41,64,65]$ and in retrospective studies [45-49]. These findings that, in particular, persistent intensive physical activity and participation in organised sport predicts best adult physical activity independent of the types of sports engaged in at a young age suggest that regular, intensive, and persistent participation results in the development of motor abilities, skills, attitudes, and motivation, all of which are important for later physical activity. This is called here the ability and readiness hypothesis, meaning that earlier experiences of physical activities and sports and of the basic skills connected with them make it easy to maintain physical activity or start it again after a possible break, even though the type of activity practised is different.

The habit formation hypothesis says that people repeat some behaviour because it is a habit, which means, for example, that participation in physical activity is not only based on planned behaviour and intention but is done rather automatically and with less awareness [66-68]. In order to form a habit, a lot of repetition of behaviour is needed. However, habit is something more than frequency of behaviour and can be distinguished from behaviour frequency. It is easy to understand that part of the physical activity behaviours, such as daily walks, daily home gymnastics, and commuting in a physically active way, are based on habits. We know very little about the tracking of habits from young age to adulthood, and therefore it is difficult to estimate the importance of the habit formation hypothesis as an explanation for the tracking of physical activity. The review showed that low activity or inactivity tracks better than activity. It may be that inactivity is more often based on a habit than high level of activity.

The self-selection hypothesis should also be taken into account as a possible explanation for the tracking of physical activity. It posits that those individuals who have a hereditary disposition to fitness and motor performance participate more often in physical activity both at a young age and in adulthood than those who do not have the same disposition. It is known that physical fitness is to a considerable extent genetically determined $[69,70]$, which gives some support to the self-selection hypothesis. Family and twin studies have shown high or moderate genetic influences on sport participation and leisure time physical activity [71, 72]. Research data showing a direct relationship between genes and physical activity in animals are still missing in humans [73]. As Rankinen and Bouchard [73] state, research on genetics, physical activity, and health is still in its infancy, but there is already substantial evidence to conclude that physical activity affects the health status and to recognize that genomes modulate the associations between activity and health at multiple levels. Although it is evident that genes regulate fitness and other physiological bases of physical activity to a large degree, it seems that genetics explains only a part of physical activity behaviour.

\section{Discussion}

The results of this review of the tracking studies show physical activity to have significantly low or moderate stability during all life phases and also in long-term follow-ups in men. In women, the level of tracking is lower and in many studies nonsignificant. In both sexes, stability seems to be lower in early childhood than in adolescence or in adulthood and lower in transitional phases, such as from childhood to adolescence or from adolescence to adulthood, than in adulthood. Especially in adolescence, the tracking is influenced by the growth which happens at a different time in different individuals. However, the differences in the stability of physical activity between age groups and between different phases of life were small. The number of tracking studies implemented using objective methods to measure physical activity was so small that systematic differences in stability could not easily be seen between self-report and objective methods. One factor which made a difference in the tracking results was the adjustment of correlations for measurement error and other error variance. Adjusted coefficients were clearly higher than unadjusted ones. Unfortunately, adjustment was done only in very few studies.

A big problem in many tracking studies is the lack of information about the validity and reliability of the assessment of physical activity. In addition to reporting the reliability of measurement, it would be important to correct stability correlations for measurement error by employing reliability information. One reason for the low tracking correlations is just the poor reliability because tracking cannot be higher than reliability if not corrected. It is highly desirable that objective methods are used in tracking studies because of their better validity and reliability compared with self-report methods. However, also data obtained using objective methods often need some correction procedures to improve the reliability and validity of the measurement instrument. Short-term variation in physical activity from day to day or between weekdays and weekend, although reliably measured with an accelerometer, means error variance when the tracking of physical activity is concerned. Also, seasonal variation can be seen as error variance from the viewpoint of long-term tracking (e.g. tracking from adolescence to adulthood). Therefore, tracking coefficients should be adjusted to take this kind of variation into account.

In spite of the large number of tracking studies, our knowledge about the tracking of physical activity is rather limited. In addition to paying more attention to the adjustments of tracking correlations for different error variations, factors influencing tracking also need to be included in study designs. A 
longitudinal study involves a lot of effort and resources, and therefore it would only be reasonable to obtain all the information possible about the covariates of tracking and not to look merely at the inter-age correlations. There is evidence that low physical activity or inactivity tracks better than high activity. Because physical inactivity is a big problem confronting public health policy, special attention should be paid to the tracking of inactivity and, in particular, to the determinants of inactivity. Especially important regarding this is the continuous increase of obesity among young people.

Since Robert Malina's review on the tracking of physical activity in 2001 [1], the quantity of tracking studies has greatly increased along with a slight increase in their quality. It is still possible to agree with his conclusion: 'Allowing for the differ- ent methods for estimating habitual physical activity, change associated with normal growth and maturation, and lack of control for important covariates in studies of tracking, physical activity tracks reasonably well from childhood to young adulthood'. In the light of the results reviewed here, the conclusion can also be extended to the tracking in the longer term. This supports the idea that the enhancement of children's and adolescents' physical activity is genuinely important from the standpoint of public health.

\section{Disclosure}

The author declared no conflict of interest.

\section{References}

1 Malina RM: Tracking physical activity across the life span. PCPFS Res Dig 2001;3:1-8.

$\checkmark 2$ Foulkes MA, Davis CE: An index of tracking for longitudinal data. Biometrics 1981;37:439-446.

3 Pühse U, Gerber M: International Comparison of Physical Education, Concepts, Problems, Prospects. Oxford, Meyer and Meyer Sport, 2005.

4 Corbin C: The untracking of sedentary living: a call for action. Pediatr Exerc Sci 2001;13:347-356.

5 Oja L, Jürimäe T: Tracking of motor abilities, physical activity, and elementary motor skills during transition from pre-school to school. Acta Kinesiol Univ Tartuensis 2001;6:91-101.

6 Hallal P, Wells J, Reichert F, Anselmi L, Victora C: Early determinants of physical activity in adolescence: prospective birth cohort study. BMJ 2006;332: 1002-1007.

7 Sallis JF, Berry CC, Broyles SL, McKenzie TL, Nader PR: Variability and tracking of physical activity over $2 \mathrm{yr}$ in young children. Med Sci Sports Exerc 1995;27:1042-1049.

8 Jackson DM, Reilly JJ, Kelly LA, Mongomery C, Grant S, Paton JY: Objectively measured physical activity in a representative sample of 3- to 4-yearold children. Obes Res 2003;11:420-425.

$\checkmark 9$ Kelly LA, Reilly JJ, Jackson DM, Montgomery C, Grant S, Paton JY: Tracking physical activity and sedentary behavior in young children. Pediatr Exerc Sci 2007;19:51-60.

10 Pate RR, Baranovski T, Dowda M, Trost SG: Tracking of physical activity among young children. Med Sci Sports Exerc 1996;28:92-96.

11 Nyberg G, Ekelund C, Marcus C: Physical activity in children measured by accelerometry: stability over time. Scand J Med Sci Sports 2009;19:30-35.

12 Raudsepp L, Päll P: Reproducibility and stability of physical activity in children. Pediatr Exerc Sci 1998; 10:320-326.

13 Baggett CD, Stevens J, McMurray RG, Evenson KR, Murray DM, Catellier DJ, He K: Tracking of physical activity and inactivity in middle school girls. Med Sci Sports Exerc 2008;40:1916-1922.

14 Raudsepp L, Neissaar I, Kull M: Longitudinal stability of sedentary behaviors and physical activity during early adolescence. Pediatr Exerc Sci 2008;20:251-262.
15 Telama R, Leskinen E, Yang X: Stability of habitual physical activity and sport participation: a longitudinal tracking study. Scand J Med Sci Sports 1996;6:371-378.

16 Aarnio M, Winter T, Peltonen J, Kujala U, Kaprio $\mathrm{J}$ : Stability of leisure-time physical activity during adolescence - a longitudinal study among 16-, 17and 18-year-old Finnish youth. Scand J Med Sci Sports 2002;12:179-185

17 Raustorp A, Svenson K, Perlinger T: Tracking of pedometer-determined physical activity: a 5-year follow-up study of adolescents in Sweden. Pediatr Exerc Sci 2007;19:228-238.

18 Janz KF, Dawson JD, Mahoney LT: Tracking physical fitness and physical activity from childhood to adolescence: the Muscatine study. Med Sci Sports Exerc 2000;32:1250-1257.

19 McMurray RG, Harrell JS, Bangdiwala SI, Hu J: Tracking of physical activity and aerobic power from childhood through adolescence. Med Sci Sports Exerc 2003;35:1914-1922.

20 Pate R, Trost SG, Dowda M, Ott A, Ward DS, Saunders R, Felton G: Tracking of physical activity, physical inactivity, and health-related physical fitness in rural youth. Pediatr Exerc Sci 1999;11:364376.

21 Richards R, Williams S, Poulton R, Reeder A: Tracking club sport participation from childhood to early adulthood. Res Q Exerc Sport 2007;78:413419.

22 Kristensen PL, Møller NC, Korsholm L, Wedderkopp N, Andersen LB, Froberg K: Tracking of objectively measured physical activity from childhood to adolescence: the European youth heart study. Scand J Med Sci Sports 2008;18:171-178.

23 Tudor-Locke C, Giles-Gorti B, Knuiman M, McCormack G: Tracking pedometer-determined physical activity in adults who relocate: results from RESIDE. Int J Behav Nutr Phys Act 2008;5:39.

24 Anderssen N, Jacobs DR, Sidney S, Bild DE, Stemfeld B, Slattery ML, Hannan P: Change and secular trends in physical activity patterns in young adults: a seven-year longitudinal follow-up in the Coronary Artery Risk Development in Young Adults Study (CARDIA). Am J Epidemiol 1996;143:351-362.

25 De Bourdeaudhuij ID, Sallis J, Vandelanotte C: Tracking and explanation of physical activity in young adults over a 7-year period. Res Q Exerc Sport 2002;73:376-385.
26 Fortier MD, Katzmarzyk PT, Malina RM, Bouchard C: Seven-year stability and musculoskeletal fitness in the Canadian population. Med Sci Sports Exerc 2001;33:1905-1911.

27 Telama R, Yang X, Viikari J, Välimäki I, Wanne O, Raitakari O: Physical activity from childhood to adulthood: a 21-year tracking study. Am J Prev Med 2005;28:267-273.

28 Kirjonen J, Telama R, Luukkonen R, Kääriä K Kaila-Kangas L, Leino-Arjas P: Stability and prediction of physical activity in 5-, 10-, and 28-year follow-up studies among industrial employees. Scand J Med Sci Sports 2006;16:201-208.

29 Friedman HS, Martin LR, Criqui MH, Kern ML, Reynolds CA: Stability of physical activity across the lifespan. J Health Psychol 2008;13:1092-1104.

30 Sallis J, Greenlee L, McKenzie TL, Broyles SL, Zive MM, Berry CC, Brennan J, Nader P: Changes and tracking of physical activity across seven years in Mexican-American and European-American mothers. Women Health 2001;34:1-14.

31 Parsons T, Power C, Manor O: Longitudinal physical activity and diet patterns in the 1958 British Birth Cohort. Med Sci Sports Exerc 2006;38:547-554.

32 Trudeau F, Laurencelle L, Shepard RJ: Tracking of physical activity from childhood to adulthood. Med Sci Sports Exerc 2004;36:1937-1943.

33 Andersen LB, Haraldsdóttir J: Tracking of cardiovascular disease risk factors including maximal oxygen uptake and physical activity from late teenage to adulthood, an 8-year follow-up study. J Intern Med 1993;232:309-315.

34 Anderssen N, Wold B, Torsheim T: Tracking of physical activity in adolescence. Res Q Exerc Sport 2005;76:119-129.

35 Boreham C, Robson P, Gallagher A, Gran J, Savage M, Murray L: Tracking physical activity, fitness, body composition and diet from adolescence to young adulthood: The Young Heart project, Northern Ireland. Int J Behav Nutr Phys Act 2004; $1: 14$.

36 Glenmark B, Hedberg G, Jansson E: Prediction of physical activity level in adulthood by physical characteristics, physical performance and physical activity in adolescence: an 11-year follow-up study. Eur J Appl Physiol Occup Physiol 1994;69:530538. 
37 Herman KM, Craig CL, Gauvin L, Katzmarzyk PT: Tracking of obesity and physical activity from childhood to adulthood; The Physical Activity Longitudinal Study. Int J Pediatr Obes 2008; DOI: 10.1080/17477160802596171.

38 Barnekow-Bergkvist M, Hedberg G, Janlert U, Jansson E: Prediction of physical fitness and physical activity in adulthood by physical performance and physical activity in adolescence - an 18-year follow-up study. Scand J Med Sci Sports 1998;8: 299-308.

\39 Beunen GP, Lefevre J, Philippaerts RM, Delvaux K, Thomis M, Claessens AL, Vanreusel B, Lysens R, Vanden Eynde B, Renson R: Adolescent correlates of adult physical activity: a 26-year follow-up. Med Sci Sports Exerc 2004;36:1930-1936.

40 Scott D, Willits FK: Adolescent and adult leisure patterns: a 37-year follow-up study. Leisure Sci 1989; 11:323-335.

41 Engström LM: Exercise adherence in sport for all from youth to adulthood; in Oja P, Telama R (eds): Sport for all. Amsterdam, Elsevier Science, 1991, pp 473-483.

42 Tammelin T, Näyhä S, Laitinen J, Rintamäki H, Järvelin MR: Physical activity and social status on adolescence as predictors of physical inactivity in adulthood. Prev Med 2003;37:375-81.

43 Matton L, Thomis M, Wijndaele K, Duvigneaud N, Beunen G, Claessens AL, Vanreusel B, Philippaerts R, Lefevre J: Tracking of physical fitness and physical activity from youth to adulthood in females. Med Sci Sports Exerc 2006;38:1114-1120.

44 Scheerder J, Thomis M, Vanreusel B, Lefevre J, Renson R, Vanden Eynde B, Beunen GP: Sports participation among females from adolescence to adulthood, a longitudinal study. Int Rev Sociol Sport 2006;41:413-430.

45 Curtis J, McTeer W, White P: Exploring effects of school sport experiences on sport participation in later life. Sociol Sport J 1999;16:348-365.

46 Kraut A, Melamed S, Cofer D, Froom P: Effect of school age sports on leisure time physical activity in adults: the CORDIS Study. Med Sci Sports Exerc 2003;35:2038-2042.

47 Powell KE, Dysinger W: Childhood participation in organized school sport and physical education as precursors of adult physical activity. Am J Prev Med 1987;3:276-281.

48 Paffenberger RS, Hyde RT, Wing AL, Steinmetz $\mathrm{CH}$ : A natural history of athleticism and cardiovascular health. JAMA 1984;252:491-495.
49 Hirvensalo M, Lintunen T, Rantanen T: The continuity of physical activity - a retrospective and prospective study among older people. Scand J Med Sci Sports 2000;10:37-41.

50 Frändin K, Mellström D, Sundh V, Grimby G: A life span perspective on patterns of physical activity and functional performance at the age of 76 . Gerontology 1995;41:109-120.

51 Telama R, Laakso L, Yang X: Physical activity and participation in sports of young people in Finland. Scand J Med Sci Sports 1994;4:65-74.

52 Allender S, Hutchisson L, Foster C: Life-change events and participation physical activity: a systematic review. Health Promot Int 2008;23:160-172.

53 Yang X, Telama R, Laakso L, Keltikangas-Järvinen L, Pulkki L: Determinants of adult physical activity; relative importance of youth physical activity and demographic, psychological, behavioural and environmental factors in adulthood. Acta Kinesiol Univ Tartuensis 2007;12:129-146.

54 Telama R, Yang X, Laakso L, Viikari J: Physical activity in childhood and adolescence as predictor of physical activity in young adulthood. Am J Prev Med 1997:13:317-323.

55 Raitakari OT, Porkka KVK, Taimela S, Telama R, Räsänen L, Viikari JS: Effects of persistent physical activity and inactivity on coronary risk factors in children and young adults. The Cardiovascular Risk in Young Finns Study. Am J Epidemiol 1994;140:195-205.

56 Vanreusel B, Renson R, Beunen G, Claessens AL, Lefevre J, Lysens R, Vanden Eynde B: A longitudinal study of youth sport participation and adherence to sport in adulthood. Int Rev Sociol Sport 1997;32:373-387.

57 Kjønniksen L, Torsheim T, Wold B: Tracking leisure-time physical activity during adolescence and young adulthood: a 10-year longitudinal study. Int J Behav Nutr Phys Act 2008;5:69-80.

58 Green K: Physical education and the "couch potato society' - part one. Eur J Phys Educ 2002;7:95-97.

59 Haywood K: The role of physical education in the development of active lifestyles. Res Q Exerc Sport 1991;62:151-156.

60 Kirk D: Physical education, youth sports and lifelong participation: the importance of early learning experiences. Eur Phys Educ Rev 2005;11:239-255.

61 Tammelin T, Näyhä S, Hills AP, Järvelin MR: Adolescent participation in sports and adult physical activity. Am J Prev Med 2003;24:22-28.
62 Laakso L: The social environment in childhood and adolescence as a predictor of adult physical activity, a retrospective study (in Finnish). Studies in Sport, Physical Education and Health 14. University of Jyväskylä, 1981

63 Telama R, Yang X, Hirvensalo M, Raitakari O: Participation in organised sport as a predictor of adult physical activity: a 21-year longitudinal study. Pediatr Exerc Sci 2006;17:76-88.

64 Perkins DF, Jacobs JE, Barber BL, Eccles JS: Childhood and adolescent sports participation as predictors of participation in sports and physical fitness activities during young adulthood. Youth Soc 2004:35:495-520.

65 Kjønniksen L, Andersen N, Wold B: Organised youth sport as a predictor of physical activity in adulthood. Scand J Med Sci Sports 2008; DOI: 10.1111/j.1600-0838.2008.00850

66 Kremers SP, Brug J: Habit strength of physical activity and sedentary behaviour among children and adolescents. Pediatr Exerc Sci 2008;20:5-17.

67 Verplanken B, Melkevik O: Predicting habit: the case of physical exercise. Psychol Sport Exerc 2008; 9:15-26.

68 Verplanken B: Beyond frequency: habit as mental construct. Br J Soc Psychol 2009;45:639-656.

69 Bouchard C, Dionne F, Simoneau J, Boulay M: Genetics of aerobic and anaerobic performances. Exerc Sport Sci Rev 1992;20:27-58.

70 Pancrazi R: Promoting physical activity for youth. J Sci Med Sport 2000;3:280-286.

71 Beunen G, Thomis M: Genetic determinants of sports participation and daily physical activity. Int J Obes 1999;3:1-9.

72 Maia JAR, Thomis M, Beunen G: Genetic factors in physical activity levels: a twin study. Am J Prev Med 2002;23:87-91.

73 Rankinen T, Bouchard C: Invited commentary: physical activity, mortality and genetics. Am J Epidemiol 2007;166:260-262.

74 Mulder M, Ranchor AV, Sanderman R: The stability of lifestyle behaviour. Int J Epidemiol 1998; 27:199-207.

75 Armstrong G, Morgan, K: Stability and change in levels of habitual physical activity in later life. Age Aging 1998;27(suppl 3):17-23.

76 Twisk JWR, Kemper HCG, Van Mechelen W: Tracking of activity and fitness and the relationship with cardiovascular disease risk factors. Med Sci Sports Exerc 2000;32:1455-1461. 